DOI https://doi.org/10.18551/rjoas.2020-12.01

\title{
ANALYSIS OF INDONESIAN ACCOUNTANT STRATEGY FACING FREE TRADE - ASEAN ECONOMIC COMMUNITIES
}

\author{
Menes, Navatilova Ulva* \\ Department of Accounting, Faculty of Economics and Business, University of Airlangga, \\ Surabaya, Indonesia \\ *E-mail: ulvanavatilova@gmail.com
}

\begin{abstract}
Accounting, accountants and professional public accountants are professions that are needed for the world of the global economy. Today, the world is united, starting from the existence of the internet to the existence of free trade such as the FTA (Free Trade Area) and ASEAN Economic Community between countries, especially Southeast Asia. This presents a challenge for the public accounting profession. The number of public accountants in Indonesia is still very low when compared to the total population and the needs of the business world. The government, IAI, IAPI, academics have taken various steps to overcome this, although not yet fully effective. ASEAN Economic Community is a challenge if the Indonesian Accountant is one of the faces of Indonesia's professional resources. If Indonesian Accountants can survive and win the ASEAN Economic Community competition at least in their own country, the future and reputation of Indonesian Accountants will be even brighter and it is not impossible that Indonesian Accountants can compete at the Asian and world levels.
\end{abstract}

\section{KEY WORDS}

ASEAN Economic Community, public accountants, CPA.

Accounting, accountants, and professional public accountants are professions that are needed for the world of the global economy. The importance of accounting and the accounting profession has been recognized in its importance since 3,600 BC and 1600s. In $3,600 \mathrm{BC}$, the oldest records of trade transactions were found in Babylon (Putri, 2010). In the 1600 s, it was recorded that the first batch of accountants had graduated from accounting education in the Netherlands. One of the first batches of accountants was George Watson from Scotland (1645-1723) (Alexander, 2002). In Indonesia, the professional accountant and public accountant profession have existed since the days of the Dutch East Indies (before Indonesia's independence). The revival of accountants began with the formation of $|A|$ on October 17, 1957, and rose even further when IAPI separated from IAI on June 4, 2007.

Today, the world is united, starting from the internet to the existence of free trade between countries. Free trade (Free Trade Area-FTA) makes the world seem to be one. Free trade allows goods, services, investment, labor, capacity building, customs procedures, intellectual property rights, and others from one country to enter another country with very low import tax (member countries only). So far, Indonesia has had many FTAs with many countries but they are usually bilateral (one or two countries only). However, in October 2003, ASEAN (the Association of Southeast Asian Countries) officials agreed on the existence of the ASEAN Economic Community. ASEAN Economic Community is a follow-up to AFTA (ASEAN Free Trade Area) which was ratified in 1992. ASEAN Economic Community is free trade for the goods, services, and investment sectors. The existence of the ASEAN Economic Community becomes two sides of the coin. On the one hand, the AEC is a challenge, and on the other hand an opportunity.

The sector that is most concerned about by Indonesia is the trade sector, especially professional services for accountants and public accountants. Indonesia, which has the largest population in ASEAN, is not directly proportional to the number of accountants and public accountants. Based on data from the AFA (ASEAN Federation of Accountants), from 2014 to 2019, the number of Indonesian accountants was still less than Singapore, Malaysia, 
and Thailand. However, the number of accountants certified by the ASEAN CPA (Certified Public Accountant) Indonesia as of December 2020 is the highest compared to other ASEAN countries. This condition made the various parties involved (government, associations, academics, and other parties) feel the need to discuss this trend.

This paper discusses the history of the emergence of public accounting and accountants both in the world and in Indonesia. This paper also discusses free trade, data related to accountants, and suggestions put forward by several parties along with discussions and conclusions.

Accounting History. The financial recording system has existed since 3,000 BC (Putri, 2010). According to historians, trading transactions have been recorded since BC. The oldest record of trade transactions comes from Babylon in 3,600 BC (Putri, 2010). Similar findings were obtained in Egypt and Greece but were not systematic and incomplete. In the 10th century, the Islamic government practiced a bookkeeping system, which was originally developed by Arab and Egyptian traders (Putri, 2010).

The development of accounting occurred when Luca Pacioli, a mathematician, wrote in 1494 about the double-entry bookkeeping system which was published in Summa de Arithmetica, Geometrica, Proportioni et Propotionalita (Putri, 2010). Material about bookkeeping in pairs is published in the book with the title Tractatus de Computis et Scriptorio (Putri, 2010). Over time, the book spread across Western Europe and was developed by many experts (Putri, 2010). In 1553, James Peele compiled a book on doubleentry with the title The Maner and fourme how to kepe a perfecte reconyng after the order of ... debitour and creditour (ICAEW, 2012). James Peele's book is the first British literature to discuss double-entry bookkeeping (ICAEW, 2012).

The pair-bookkeeping system then developed under the name of the system which mentions the country of origin, for example, the Dutch system (continental system), the British system (the anglo-Saxon system), and the United States system (the anglo-Saxon system) (Putri, 2010). The development of accounting moved from the continental system to the anglo-Saxon system. In medieval times, the center of trade moved from Venice to Western Europe (Putri, 2010). Western Europe, especially Britain, became the center of trade during the industrial revolution. During the industrial revolution, accounting developed rapidly. At the end of the 19th century, a bookkeeping system called accounting developed in the United States (Putri, 2010).

History of Accountant Profession. At the beginning of the development of accounting, the accounting system adopted was a continental accounting system based in the Netherlands (Dutch system). One of the early Scottish accountants who graduated from accounting training in the Netherlands was George Watson (1645-1723) (Alexander, 2002). Meanwhile, accounting firms (firms of accountants) were first established in Bristol, England, in the 1780s (ICAEW, 2012). Towards the middle of the 19th century, England was in the middle of the heyday brought by the Industrial Revolution (Alexander, 2002). At that time, the demand for accountants competed fiercely (Alexander, 2002).

In the early 18th century, the services of a London-based accountant were used in an investigation by the director of the South Sea Company (Putri, 2010). The director is currently trading the company's stock exchange. During this investigation, the accountants examined at least two of the company's books. Her report is described in the book Sawbridge and Company, by Charles Snell, Writing Master and Accountant in Foster Lane, London (Putri, 2010). The United States owes the concept of objectives related to Registered Public Accountants to Britain which already had Chartered Accountants in the 19th century (Putri, 2010). The contribution of the Renaissance to accounting, among others, is the emergence of accounting terms used today, including debt, debtor, debenture, debit, credit, creed, and credere. Besides, they have started the development of cost accounting, accrual, deferred, and balance sheet audits (Putri, 2010).

In 1880, the newly formed Institute of Chartered Accountants in England and Wales brought together all the accounting organizations in the country (Alexander, 2002). The initial members numbered 587. Then there was an additional 606 members who were recruited based on their experience. Then, standards of conduct and examinations for admission to 
the Institute are developed. Members began to use the designations "FCA" (Fellow Chartered Accountant, for partner companies or practice providers) and "ACA" (Associate Chartered Accountant, denoting a qualified member of the accounting staff, or nonpractitioner member) (Alexander, 2002).

In the late 1800s, a large amount of British capital flowed into the fast-growing industries in the United States. Scottish and British accountants went to the United States to audit investments and some of them remained and practiced in America (Alexander, 2002). Some of the existing American accounting firms are Scottish and British chartered accountants who migrated to the United States. In 1850, there were 14 accountants in public practice in New York, 4 in Philadelphia, and 1 in Chicago. In 1886, there were 115 accountants in New York, 87 in Philadelphia, and 31 in Chicago (Alexander, 2002). A group of accountants joined to form professional groups in cities across America. (Alexander, 2002).

In 1887, the first national accounting group was formed under the name American Association of Public Accountants (AAPA) (Alexander, 2002). AAPA is the forerunner of the American Institute of Certified Public Accountants (AICPA). In 1916, AAPA was replaced by the Institute of Public Accountants and has 1,150 members (www.aicpa.org). In 1917, the name Institute of Public Accountants was changed to the American Institute of Accountants until 1957 (www.aicpa.org). In 1921, the American Society of Certified Public Accountants was formed to act as the state's Federation of societies (www.aicpa.org). In 1936, the American Society of Certified Public Accountants joined the American Institute of Accountants (www.aicpa.org). Following the merger, the American Institute of Accountants agreed to impose restrictions on CPA members (www.aicpa.org). In 1957, the American Institute of Accountants changed its name to AICPA (www.aicpa.org).

History of Indonesian Accountants. During the Dutch colonial period, Indonesia was made a colony called the Dutch East Indies. At that time, all regulations related to public accounting were controlled by the Dutch East Indies Government. Dutch Indies accountants were accommodated in one of the organizations formed by the Dutch East Indies Government and their numbers were still small. The Dutch government has 2 accounting organizations, namely (Tuanakotta, 2015: B38-39):

1. NIVA (Netherlands Instituut van Accountants) which was founded in 1895;

2. VAGA (Vereniging van Academish gevormde Accountants) was founded in 1927.

In 1967, NIVA and VAGA merged to become NIVRA (Nederlands Instituut van Registera Accountants).

The history of accounting development in Indonesia is closely related to the history of politics and trade in Indonesia. In the colonial era until 1955, the way to obtain the title of the accountant was through formal and non-formal education (courses) (Putri, 2010). From 1955 to 1979 the title of the accountant was awarded. The Accounting Department was first opened at the University of Indonesia in 1954 based on Law No. 34 of 1954 (UU No. 21 Tahun 1989) (Putri, 2010). However, the law turned out to be controversial, namely (Putri, 2010):

1. Those allowed to educate prospective accountants are the economics faculties of state universities. This statement raises the perception that private universities are not allowed to produce accountants;

2. Education leads to public accounting education.

From 1980 to 2000, the opportunity for PTS graduates to obtain the title of the accountant was opened through the State Accounting Examination (UNA) mechanism (Putri, 2010). Besides, based on Law no. 21 of 1989 a person can obtain the title of accountant on the condition that someone has a Bachelor of Economics degree. In 1997, an accountant practice license was only given to those who had taken the USAP (Public Accountant Certification Exam) after which they could only get BAP (Putri, 2010). From 2001 until now a new mechanism was born in line with the issuance of the Minister of Education and Culture Decree No. 056/ U/1999 (SK Mendikbud No. 056/U/1999) starting September 2002 the title of the accountant is not a monopoly of state universities (Putri, 2010). Also, since the enactment of the Minister of National Education Decree 179/ U/ 2001 (SK Mendiknas 179 /U 
/2001) undergraduate students majoring in PTN accounting must study at PPA (Accounting Professional Education) for a maximum of 2 years before they can produce a degree and register as an accountant. Since the enactment of the decree, the decree that allows only state universities to produce accountants is limited to 31 August 2004 before finally PPA can be held by all universities that meet the requirements and are recommended by the IAI (Indonesian Accountants Association) through the Expert Committee (Putri, 2010). To support the smooth running of PPA, the Minister of National Education issued the Minister of National Education Decree No. 180 / P / 2001 regarding the appointment of the Expert Committee for the Consideration of Accountants' Diploma (Putri, 2010).

Today, the organization that houses accountants is the IAI (Indonesian Accountants Association). IAI was born from the Indonesian spirit and the assumption that NIVA and VAGA can't care about the development and development of accountants in Indonesia (Tuanakotta, 2015: B38-39). On October 17, 1957, the leaders held a meeting and decided to ask their opinion from Indonesian accountants regarding the establishment of an accountants association. On 23 December 1957 at 07.30, the IAI (Indonesian Accountants Association) was formed (Tuanakotta, 2015: B38-39). The following is the development of Financial Accounting Standards in Indonesia:

Table 1 - Development of Financial Accounting Standards

\begin{tabular}{|c|c|}
\hline Date & Events \\
\hline $\begin{array}{l}\text { Before December } \\
2,1973\end{array}$ & $\begin{array}{l}\text { Here was no accounting standard / accounting principle. Accounting practice in Indonesia is } \\
\text { guided by accounting principles in the Netherlands or the United States. }\end{array}$ \\
\hline $\begin{array}{l}\text { December 2, } \\
1973\end{array}$ & $\begin{array}{l}\text { Indonesian Accounting Principles (PAI) were prepared based on the US-GAAP-Inventory of } \\
\text { GAAP for Business Enterprises by Paul Grady. }\end{array}$ \\
\hline 1984 & Prepared 1984 Indonesian Accounting Principles (revised PAI 1973). \\
\hline Date & Events \\
\hline 1994 & $\begin{array}{l}\text { - Harmonization of PAI with IAS (International Accounting Standards) compiled by IASC } \\
\text { (International Accounting Standards Committee). } \\
\text { - } \quad \text { PAI changed its name to Statement of Financial Accounting Standards. } \\
\text { - Started the adoption of KDPPLK (Basic Framework for the Preparation and Presentation } \\
\text { of Financial Statements) which was taken from the Conceptual Framework IAS. }\end{array}$ \\
\hline 2004 & IFRS adoption plans are announced in 2008 \\
\hline 2006 & Revised adoption target to 2010 \\
\hline 2008 & Revised adoption target to 2012 \\
\hline July 2009 & $\begin{array}{l}\text { Changed the terms of adoption to convergence and clarified the target date for convergence } \\
\text { is } 2012 \text {. }\end{array}$ \\
\hline January 1, 2012 & $\begin{array}{l}\text { IFRS convergence phase } 1 \text { based on IFRS version January 1, } 2009 \text { came into effect in } \\
\text { Indonesia. }\end{array}$ \\
\hline 2013 & $\begin{array}{l}\text { Convergence of IFRS phase } 2 \text { which will take effect in } 2015 \text { by reducing the gap between } \\
\text { IFRS and PSAK to } 1 \text { year.. }\end{array}$ \\
\hline January 1,2015 & IFRS convergence phase 2 based on IFRS version January 12014. \\
\hline January 1,2016 & IFRS Convergence. Issued SAK effective as of January 1, 2016 \\
\hline January 1, 2017 & IFRS Convergence. Issued SAK effective January 1, 2017 \\
\hline January 12018 & Issued SAK effective as of January 1, 2018 \\
\hline January 1,2019 & Issued SAK effective as of January 1, 2019 \\
\hline January 1,2020 & $\begin{array}{l}\text { Issuance of SAK effective as of January 1, } 2020 \text { Based on IFRS except PSAK number } 28 \\
\text { and } 38 .\end{array}$ \\
\hline
\end{tabular}

Source: Kartikahadi, Sinaga, Syamsul, Siregar, and Wahyuni (2016, pp. 14-27) and IAI.

IAPI (Indonesian Public Accountants Association) is an organization that houses Public Accountants in Indonesia. Initially, IAPI was part of a section or compartment in IAI named IAI-Section Public Accountants (IAI-SAP) (Tuanakotta, 2015: B38-39). IAPI was created on April 7, 1978, chaired by Tuanakotta (Tuanakotta, 2015: B38-39). IAl made the first accounting and auditing standards (Tuanakotta, 2015: B38-39) following the reactivation of the Indonesian capital market on August 10, 1977, following the Presidential Decree. No. 25 of 1976(Kepres RI. No. 25 Tahun 1976) (Tuanakotta, 2015: B41). The first accounting standard is called the Indonesian Accounting Principles, while the first auditing standard is called Accountant Audit Norms (Tuanakotta, 2015: B41). On May 24, 2007, IAI - the Public 
Accountants Compartment (the designation of sections is replaced by compartments) changed to an independent association separate from IAI under the name Indonesian Institute of Public Accountants (IAPI) (Tuanakotta: 2015: B43). On June 4, 2007, IAPI was officially accepted as an associate member within the IAI environment (Tuanakotta: 2015: B43). On February 5, 2008, through the Minister of Finance Regulation Number 17 / PMK.01 / 2008 (Peraturan Menteri Keuangan Nomor 17/PMK.01/2008), IAPI was officially accepted as a public accounting professional organization which has the authority to (Tuanakotta: 2015: B43):

- Conduct a public accountant certification exam;

- Develop and publish professional and ethical standards for public accountants;

- Organizing a continuing education program (PPL) for all public accountants.

Public Accountant Professional Standards are standards that help auditors fulfill their professional responsibilities related to auditing financial statements. These standards include considerations of professional qualifications such as competence and independence, reporting requirements, and evidence (Elder et al, 2011: 41). The most recent Public Accountant Professional Standards refer to the ISA (International Standard of Auditing).

The Code of Ethics for the Professional Public Accountant is a rule that provides a general standard of ideal behavior and rules of conduct that govern behavior (Elder et al., 2011: 70). Ethics is one of the main elements of the profession which forms the basis for accountants in carrying out their professional activities (IAI, 2016). Accountants have a responsibility to act in the public interest (IAI, 2016). The code of ethics for the public accounting profession was prepared by IAI in coordination with IAPI (Indonesian Institute of Public Accountants) and IAMI (Institute for Management Accountants) according to a memorandum of understanding (IAI, 2016). The most recent code of ethics for the public accounting profession is the Code of Ethics for the Public Accountants in 2020 which is based on the Handbook of the International Code of Ethics for Professional Accountants including the International Independence Standards 2018 Edition (IAPI, 2020).

Global Competition and Public Accountant. Today, global competition from the goods and services sector is inevitable. Global competition in the goods sector has probably been experienced for a long time since the existence of imports and exports. However, global competition in the service sector, especially professional services, was only felt when Indonesia entered into a free trade agreement. Free Trade Agreement (Free Trade Agreement) is an agreement between two or more countries to form a free trade area where trade in goods or services between these countries can cross the borders of their respective countries without being subject to tariff barriers or non-tariff barriers (www.kemendag. go.id).

FTA (Free Trade Agreement) has several benefits for its members, some of which are the formation of trade creation and trade diversion (www.kemendag.go.id). Trade creation is the creation of trade transactions between FTA members that have never occurred before, as a result of incentives due to the formation of the FTA (www.kemendag.go.id). Trade diversion is an event that occurs as a result of tariff reduction incentives (www.kemendag.go.id). Bilateral and regional FTAs include trade in goods, trade in services, investment, movement of labor, capacity building, customs procedures, intellectual property rights, and so on (www.kemendag.go.id). The FTA that is of great concern to Indonesia is the Asean Economic Community (ASEAN Economic Community) which took effect from 2015.

ASEAN Economic Community has a wider coverage of cooperation dimensions than AFTA (Amri, 2015: 4). The impact of the creation of the AEC is free trade in the fields of capital, goods and services, and labor (http://nationalgeographic.co.id). In the field of economics (http://nationalgeographic.co.id).

There are several impacts from the consequences of the AEC, namely the unlimited trade flow of goods, services, investment, skilled labor, and free flow of capital between ASEAN countries. (http://nationalgeographic.co.id). The application of AEC for trade in goods began on December 31, 2015 (Amri, 2015: 4). On the trade side of goods, Indonesia does not need to worry too much because since the last 5 years tariff-free has been applied to 99\% of goods in ASEAN (Amri, 2015: 4). For the service sector, especially for professionals, the implementation is carried out in stages and the implementation of liberalization 
commitments will still exceed 31 December 2015 (Amri, 2015: 4). One of the concrete steps taken by the ASEAN Federation of Accountants to welcome the ASEAN Economic Community is by creating a certification for public accountants called the ASEAN CPA. Public accountants who are ASEAN CPA certified can carry out audit assignments in all ASEAN countries without having to undergo training or special qualification tests (ASEANCPA.org). On the one hand, it provides opportunities but on the other hand, it provides challenges. Accountants and public accountants are included in professional services. Accountants face big challenges related to this ASEAN Economic Community. The following shows a comparison of the population compared to the number of public accountants.

Table 2 - Comparison of Public Accountants with Population in 4 countries

\begin{tabular}{|c|c|c|c|}
\hline Country & $\begin{array}{c}\text { Total Population at } \\
2019\end{array}$ & $\begin{array}{c}\text { Amount of Public } \\
\text { Accountants }\end{array}$ & $\begin{array}{c}\text { Amount of Certified Accountants by ASEAN CPA } \\
\text { as of December 2020 }\end{array}$ \\
\hline Indonesia & 270.625 .568 & 27.985 & 1.850 \\
\hline Malaysia & 31.949 .777 & 36.178 & 1.121 \\
\hline Thailand & 69.625 .582 & 85.258 & 693 \\
\hline Singapura & 5.703 .569 & 32.643 & 757 \\
\hline
\end{tabular}

Source: https://data.worldbank.org/; https://aseancpa.org/; Annual Report ASEAN Federation of Accountants.

\section{DISCUSSION OF RESULTS}

The ASEAN Economic Community, especially in the professional accountant services sector, creates its own concerns. These concerns were felt by the government, professional associations, academics, and other related parties. The following is a summary of the proposed strategies from various parties to address the AEC:

1. Collaborating with foreign Public Accounting Firms (KAP), especially Big4 (Former Head of the Center for Financial Professional Development, Langgeng Subur and Secretary-General of the Ministry of Finance, Hadiyanto through http://finansial.bisnis.com).

2. Preparing skills, creativity, and innovation (Chairman of the East Java National Association of Indonesian Consultants (Inkindo), Adi Prawito in http://edukasi.kompas.com).

3. The government issued Regulation of the Minister of Finance No.25 / PMK.01 / 2014 concerning State Registered Accountants which was updated by Regulation of the Minister of Finance Number 216 / PMK.01 / 2017 concerning Registered Accountants.

4. Maintain and update skills on an ongoing basis (http://iaiglobal.or.id).

5. Collecting data related to accountants and the accounting industry regularly updated (DSAK IAI member, Ersa Tri Wahyuni via http://etw-accountant.com).

6. Empowerment of the accounting standards board (IAI DSAK member, Ersa Tri Wahyuni via http://etw-accountant.com).

7. Providing incentives to the accounting industry that is a beginner or small scale (DSAK IAI member, Ersa Tri Wahyuni via http://etw-accountant.com).

8. Strict supervision of accountant products (DSAK IAI member, Ersa Tri Wahyuni via http://etw-accountant.com).

9. IAI and IAPI must affirm their mission to protect the public interest and not only the interests of their group (IAI DSAK member, Ersa Tri Wahyuni via http://etwaccountant.com).

10. Accountants must maintain the integrity and public trust (Former Vice President Jusuf Kalla via https://bandung.merdeka.com).

In taking steps to overcome competition for public accounting services in ASEAN, several things need to be considered, including:

1. The number of accountants in Indonesia is still very low. Judging from the ratio of population and population of Indonesia (2015) is $1: 9,670$. This indicates that many 
new accountants are needed. Students must be motivated and given more intensive explanations regarding the accounting profession.

2. Today, very few students are interested in becoming public accountants. The reason for this must be sought because if allowed to do so, it will further threaten the population of Indonesian accountants.

3. The accountant profession is still something "big" and seems difficult to reach because of its long education span and requires a lot of money. The government should be able to provide integrated scholarships, where the scholarships fund everything from college, professional education, to accountant certification exams.

4. The government should be more pro-active in preparing Indonesian Accountants through their institutions.

5. Government policies related to the use of foreign workers. The government should provide policies related to the use of labor, in particular, in consulting services midwives so that professional consultants from Indonesia still have a place. These policies may be implemented in the fields of education, recruitment of employees (percentage of foreign and local experts), and related to demography (foreign experts must stay at least a few months, followed by several conditions to build love for Indonesia).

\section{CONCLUSION}

Global competition in the form of the ASEAN Economic Community (AEC) is unavoidable. The ASEAN Economic Community comes with opportunities and challenges. Indonesian accountants as part of the ASEAN Economic Community must always be prepared and optimistic. In terms of the statistical data that the author has disclosed, it can be seen that the number of Indonesian accountants is still below Malaysia, Singapore, and Thailand, whose population and territory are smaller than Indonesia. The government and related parties such as IAI, IAPI, and educational institutions have done many ways to stimulate accounting graduates to become public accountants. However, it seems that even harder efforts are needed to balance the number of public accountants with the needs of the Indonesian, ASEAN, and even global business world.

The ASEAN Economic Community is not something that can be underestimated. The government and associations, academics, and other related parties must work hard, very hard to be able to solve this Indonesian Accountant problem. The ASEAN Economic Community must be used as a trigger, not a barrier to the development of Indonesian Accountants. Indonesian accountants are one of the many faces of Indonesia's professional resources. If Indonesian Accountants can survive and win the competition of the ASEAN Economic Community at least in their own country, the future and reputation of Indonesian Accountants will be even brighter, and Indonesian Accountants can compete at the Asian and world levels.

\section{REFERENCES}

1. Alexander, J.R. 2002. History of Accounting. Association of Chartered Accountants in the United States

2. Amri, I.S. 2015. MEA Peluang Bersyarat. Buletin Masyarakat ASEAN.

3. Annual Report ASEAN Federation of Accountant 2019. 2019. ASEAN Federation of Accountant. Hal. 42.

4. Elder et. al. 2011. Jasa Audit and Assurance: Pendekatan Terpadu (Adaptasi Indonesia). Jakarta: Salemba Empat.

5. Eprints.binadarma.ac.id, diakses tanggal 24 April 2017.

6. Feri Kristianto. 2016. Kemenkeu: Akuntan Publik Sebaiknya Berkolaborasi Hadapi MEA, diakses melalui http://finansial.bisnis.com/read/20160120/55/511293/kemenkeu-akuntanpublik-sebaiknya-berkolaborasi-hadapi-mea pada tanggal 23 April 2017. 
7. https://aseancpa.org/index.php/asean-cpa/what-is-asean-cpa, diakses tanggal 11 Desember 2020.

8. Electronic

Source: http://bisniskeuangan.kompas.com/read/2014/03/11/1621393/Hadapi.MEA.Menkeu. Keluarkan. Aturan.Akuntan.Beregister.Negara, diakses tanggal 23 April 2017.

9. Electronic Source: http://data.worldbank.org/country/indonesia, diakses tanggal 11 Desember 2020.

10. Electronic Source: http://data.worldbank.org/country/thailand, diakses tanggal 11 Desember 2020.

11. Electronic Source: http://data.worldbank.org/country/singapore, diakses tanggal 11 Desember 2020.

12. Electronic Source: http://data.worldbank.org/country/malaysia, diakses tanggal 11 Desember 2020.

13. Electronic Source: http://edukasi.kompas.com/read/2016/03/21/16170011/, diakses tanggal 23 April 2017.

14. Electronic Source: http://elib.unikom.ac.id/, diakses tanggal 24 April 2017.

15. Electronic Source: http://etw-accountant.com/tag/g20/, diakses tanggal 23 April 2017.

16. Electronic Source: http://iaiglobal.or.id/v03/berita-kegiatan/detailarsip-511, diakses tanggal 23 April 2017.

17. Electronic Source: http://iaiglobal.or.id/v03/standar-akuntansi-keuangan/sak\#, diakses tanggal 11 Desember 2020.

18. Electronic Source: http://iapi.or.id, diakses 11 Desember 2020.

19. Electronic Source: http://nationalgeographic.co.id/berita/2014/12/pahami-masyarakatekonomi-asean-mea-2015, diakses tanggal 26 April 2017.

20. Electronic Source: http://www.kemendag.go.id/id/faq\#top, diakses tanggal 26 April 2017. https://www.aicpa.org/about/missionandhistory/pages/history\%20of\%20the\%20aicpa.asp X, diakses tanggal 24 April 2017.

21. IAI. 2016. Exposure Draft Kode Etik Akuntan Profesional.

22. ASEAN Federation of Accountant. 2019. Annual Report of ASEAN Federation of Accountantant 2019.

23. IAPI. 2020. Kode Etik Profesional Akuntan Publik.

24. Kementerian Keuangan. 2014. Peraturan Menteri Keuangan No.25/PMK.01/2014 tentang Akuntan Beregister Negara.

25. Kementerian Keuangan. 2017. Peraturan Menteri Keuangan Nomor 216/PMK.01/2017 tentang Akuntan Beregister.

26. Kartikahadi, H., Sinaga, R. U., Syamsul, M., Siregar, S. V., \& Wahyuni, E. T. 2016. Akuntansi Keuangan berdasarkan SAK Berbasis IFRS. Jakarta: Ikatan Akuntan Indonesia.

27. Putri, Anisa. 2010. Perkembangan Akuntansi di Indonesia. Jurnal Riset Akuntansi and Keuangan, Vol.2 Hal. 38-39.

28. Tuanakotta, T.M. 2015. Audit Kontemporer. Jakarta: Salemba Empat.

29. Electronic Source: www.aseanaccountants.org, diakses 11 Desember 2020. 